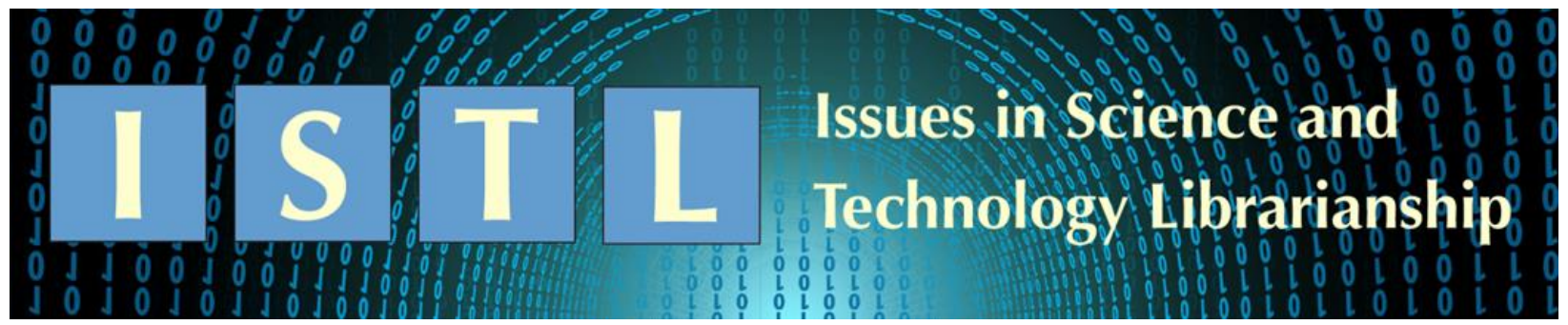

\title{
Roles for Health Sciences Librarians at College and University Libraries
}

\author{
Jason B. Reed \\ Assistant Professor of Library Science \\ Health Sciences Information Specialist \\ Purdue University \\ West Lafayette, IN \\ reed252@purdue.edu \\ Alexander J. Carroll \\ Librarian for STEM Research \\ Vanderbilt University \\ Nashville, TN \\ alex.carroll@vanderbilt.edu
}

\begin{abstract}
This study sought to examine the landscape for library positions supporting health sciences research and teaching. We investigated whether emerging research practices in health-related research at college and research universities are being accompanied by job opportunities for health sciences librarians at college and university libraries (C\&ULs). We collected position advertisements posted to relevant job boards and mailing lists between September 1, 2018 and March 1, 2019 to compare job opportunities at C\&ULs with similar opportunities at Association of Academic Health Sciences Libraries (AAHSL). We found that C\&ULs across the United States are interested in hiring librarians that are capable of supporting health and life sciences teaching and research. A qualitative content analysis of these position advertisements revealed substantial overlap in the desired qualifications and the roles and responsibilities listed for health sciences librarian positions at both types of institutions. Qualifications at both types of institutions placed a greater emphasis on traditional librarian competencies (e.g., reference services, collection management, literature searching) rather than emerging areas of expertise, such as data science skills, grant experience, and research impact assessment.
\end{abstract}

\section{Introduction}

In contemporary research, there is considerable interest among bench scientists and clinical researchers in using multidisciplinary approaches to solve complex problems in the health sciences. Examples of this include using systems engineering approaches like human factors to improve patient safety (Holden et al. 2013) and civil engineers collaborating with hospital administrators to design resilient facilities in regions prone to earthquakes (Cimellaro et al. 2010). With funding agencies like the National Science Foundation prioritizing multidisciplinary research projects in the health sciences, research libraries have a clear incentive to create 
positions and design services that support these projects (National Science Foundation n.d.). These collaborative research projects include a diverse cast of contributors from many different institutions, including hospital-based clinicians, clinical faculty at schools of medicine, and bench scientists at research universities, creating challenges for subject-based library organizations that may not have the staffing, services, or collections necessary to support these research teams' information and data needs (Hurd 1992; Knapp 2012). Yet, while the literature has seen frequent discussions of the future roles for liaison librarians within academic libraries (Rodwell \& Fairbairn 2008; Hahn 2009; Jaguszewski \& Williams 2013; Hoodless \& Pinfield 2018; Rockenbach 2018), there has been comparably little examination of whether the subject areas supported by academic librarians has kept pace with growing opportunities to support health sciences research. In this study, we sought to answer two research questions: are emerging research practices for conducting health-related research at college and research universities being accompanied by job opportunities for health sciences librarians at college and university libraries; and how do these positions compare to similar positions at academic health sciences libraries.

\section{Literature Review}

Using position descriptions to determine changing priorities within research libraries is a wellestablished method within the literature (Reser \& Schuneman 1992; Beile \& Adams 2000; Triumph \& Beile 2015). In addition to looking at the desirability of specific skills (Mathews \& Pardue 2009) or preferred educational backgrounds (Grimes \& Grimes 2008), previous studies also have analyzed position descriptions using factors like Carnegie Classifications (Trei 2015). Using position descriptions as a research artifact presents noteworthy limitations, including job advertisements that are complex, text-based documents containing ambiguous language that must be interpreted critically rather than literally. Critics of this research method have suggested that future studies include "content analysis (e.g., what lies underneath this advertisement)" rather than relying exclusively on straightforward data collection and analysis to generate insights (Hernon \& Schwartz 2015). Furthermore, the structure and content of position descriptions are often heterogeneous, which can create complications when trying to compare position descriptions across different institutions and across different time periods. Bychowski et al. (2010) suggested that in addition to considering listed qualifications and education requirements, future researchers analyze the explicitly identified roles and responsibilities listed within position descriptions in order to detect trends that might not be reflected elsewhere in the listing. Previous studies have examined areas of overlap between research support services designed for Science, Technology, Engineering, and Mathematics (STEM) researchers and those designed for health sciences professionals (Carroll et al. 2020). While obvious physical differences exist between basic science laboratories and clinical settings, the literature suggests that these ostensibly dissimilar user communities share a number of relevant characteristics, including their information seeking behaviors (Leckie et al. 1996) and their need to manage and interact with research data (Reed \& Butkovich 2017).

\section{Methods}

\section{Data Collection}

We compared opportunities at college and university libraries (C\&ULs) with similar opportunities at Association of Academic Health Sciences Libraries (AAHSL), which is an organization of libraries that serve Association of American Medical Colleges (AAMC) accredited U.S. medical schools and other libraries that operate within the broader health care environment (Association of Academic Health Sciences Libraries 2019). We used membership 
in the Association of Academic Health Sciences Libraries (AAHSL) to classify whether an institution was an AAHSL or a C\&UL institution (Carroll \& Reed 2019a).

We collected position advertisements posted to relevant job boards and mailing lists between September 1, 2018 and March 1, 2019, referred to as posted position descriptions (PPDs) hereafter. The boards and lists searched included ALA JobLIST, MLA Find a Job, ACRL HSIG, MEDLIB-L, and ACRL STS-1 (Association of College \& Research Libraries Health Sciences Interest Group 2019; Association of College \& Research Libraries Science \& Technology Section 2019; Medical Library Association 2019a; Medical Library Association 2019b; American Library Association n.d.). We supplemented searches of these boards with hand searching, defined as identifying job advertisements in a non-systematic fashion. Hand searched sources included alumni job listservs and general library job lists that the authors are subscribers to, but do not have publicly searchable archives that allow for a thorough scraping of PPDs. Job posting title, qualifications, and roles and responsibilities were searched using keywords: medic*, health, life, nursing, veterinary, bio*, pharma*. Each identified posting was reviewed for inclusion by one of the authors. To be included in the study, a PPD needed to indicate that the incumbent would directly support health sciences research. Front-line librarian and managementlevel positions were included (if the management position also included one or more front-line, health sciences research-related duties); excluded from this study were non-professional library positions (e.g., paraprofessional, library assistant, graduate assistant, etc.) and library administrative positions (e.g., Director, Associate Director, etc.). Purdue University's Institutional Review Board (IRB) reviewed this study's experimental design and determined that it did not meet the definition of human subjects research as defined by 45 CFR 46 (IRB Protocol \#1809021058).

In total, 104 unique PPDs met our inclusion criteria. Different $\mathrm{N}$ values are reported across both groups (AAHSL and C\&UL) and the three main sections investigated (required qualifications, preferred qualifications, and roles and responsibilities). This reflects the heterogeneity of PPDs; not every posting included all of the major sections analyzed.

\section{Quantitative Data Analysis Methods}

We categorized PPDs by institution type, AAHSL or C\&UL, and geographic region. To depict a posting's geographic region, we recorded both the state of the institution and the National Network of Libraries of Medicine (NNLM) region for that state (National Network of Libraries of Medicine 2019). Table 1 provides a complete listing of NNLM Region membership by state and territories.

\section{Qualitative Data Analysis Methods}

To identify prominent themes within both qualifications and roles and responsibilities listed within the collected PPDs, we used a modified grounded theory approach (Glaser \& Strauss 2000). Grounded theory is an inductive research method, through which researchers identify themes and form theories from data, rather than using existing theories to interpret data. Grounded theory uses what is often described as a coding process, in which key phrases are identified from a dataset and then grouped into broader thematic categories (Birks \& Mills 2011). This process occurs iteratively, with new phrases being identified continuously and categories being merged and collapsed throughout the process until prominent themes emerge. Grounded theory allowed us to identify key terms and phrases organically rather than prepopulating a list of terms and codes prior to data analysis, which was necessary given the degree of heterogeneity with respect to structure and language used within the PPDs. We conducted a 
Table 1. NNLM Region membership.

\begin{tabular}{|l|l|l|}
\hline \multicolumn{1}{|c|}{$\begin{array}{c}\text { Region Number } \\
\text { and Name }\end{array}$} & \multicolumn{1}{c|}{$\begin{array}{c}\text { Region } \\
\text { Abbreviation }\end{array}$} & \multicolumn{1}{c|}{ Member States and Territories } \\
\hline 1. Middle Atlantic & MAR & DE, NJ, NY, PA \\
\hline $\begin{array}{l}\text { 2. } \\
\text { Southeastern/Atlantic }\end{array}$ & SEA & $\begin{array}{l}\text { AL, DC, FL, GA, MD, MS, NC, PR, SC, TN, VI, } \\
\text { VA, WV }\end{array}$ \\
\hline 3. Greater Midwest & GMR & IL, IN, IA, KY, MI, MN, ND, OH, SD, WI \\
\hline 4. MidContinental & MCR & CO, KS, MO, NE, UT, WY \\
\hline 5. South Central & SCR & AR, LA, NM, OK, TX \\
\hline 6. Pacific Northwest & PNR & AK, ID, MT, OR, WA \\
\hline 7. Pacific Southwest & PSR & AZ, CA, HI, NV, Pacific Basin Territories \\
\hline 8. New England & NER & CT, ME, MA, NH, RI, VT \\
\hline
\end{tabular}

two-cycle coding process that involved a first round of descriptive coding (Saldana 2015), followed by consolidation of our preliminary categories into a final list of themes. For example, individual categories of "interpersonal skills," "communication skills," and "collaboration skills" were consolidated into a single theme of "collaboration, communication, and interpersonal skills." This approach also allowed us to conduct the type of in-depth content analysis that has been absent from previous studies (Hernon \& Schwartz 2015); since we were not bound to strictly quantifying the number of explicit references to specific duties and were able to uncover overarching trends that might otherwise have been obscured by slight deviations in exact diction, syntax, or phrasing.

NVivo 12, a software program developed to facilitate qualitative and mixed methods research that allows you to search (query) qualitative data sets for thematic matches, was used following our descriptive coding to search within the major sections of the PPDs: required qualifications, preferred qualifications, and roles and responsibilities. Using NVivo 12, we quantified the number of references to what previous studies have identified as the emerging roles for health sciences librarians (e.g., data science skills, research impact assessment, and experience with grant support) that did not emerge as major themes during our descriptive coding process (Crum \& Cooper 2013). Text queries were created for each theme using a combination of keywords and the most appropriate query setting; the authors used exact match, stemmed words, and synonyms as appropriate. The exact queries used can be viewed online via the Open Science Framework (OSF) (Reed \& Carroll 2019). Each query was run for all three fields of interest for both AAHSL and C\&UL PPDs. NVivo 12 would highlight each match, which was then reviewed for inclusion as a match to that theme. In our results, we report the most prominent themes from each major section of the PPDs: required education, preferred education, required qualifications, preferred qualifications, and roles and responsibilities. We also include noteworthy themes that we expected to see in these sections, but did not appear. Statistical significance was calculated using Fisher's exact test, the preferred measure for smaller sample sizes (Korosteleva 2018). 


\section{Results}

\section{Quantitative Analysis}

A full list of the PPDs included in this study is available via OSF (Carroll \& Reed 2019b). Of the 104 positions that met our inclusion, 60 were at AAHSL institutions and 44 were at C\&ULs institutions. The geographic distribution of AAHSL and C\&UL vacancies by NMLM Region and postings per capita is shown in Table 2. These positions were located throughout the country, with at least one position in 32 unique states and all 8 NNLM Regions.

Table 2. Job postings by NNLM Region, institution type, and postings per capita.

\begin{tabular}{|c|c|c|c|c|c|}
\hline \multirow{2}{*}{$\begin{array}{c}\text { Region } \\
\text { Abbreviation }\end{array}$} & \multicolumn{3}{|c|}{ Job Postings } & \multirow{2}{*}{$\begin{array}{c}\text { Region } \\
\text { Population }^{\mathrm{a}}\end{array}$} & \multirow{2}{*}{$\begin{array}{c}\text { Postings per } \\
10,000,000 \text { people }\end{array}$} \\
\hline & AAHSL & C\&UL & Total & & \\
\hline MAR & 10 & 6 & 16 & $82,301,778$ & 3.8 \\
\hline SEA & 15 & 15 & 30 & $61,809,921$ & 3.7 \\
\hline GMR & 11 & 7 & 18 & $20,401,631$ & 2.9 \\
\hline MCR & 4 & 2 & 6 & $20,401,631$ & 2.9 \\
\hline SCR & 9 & 3 & 12 & $42,414,155$ & 2.8 \\
\hline PNR & 2 & 2 & 4 & $15,280,255$ & 2.6 \\
\hline PSR & 6 & 6 & 12 & $51,454,166$ & 2.3 \\
\hline NER & 3 & 3 & 6 & $14,853,290$ & 4.0 \\
\hline \multicolumn{6}{|c|}{$\begin{array}{l}\text { a Population obtained from Annual Estimates of the Resident Population for the United States, } \\
\text { Regions, States, and Puerto Rico: April 1, } 2010 \text { to July 1, } 2019 \text { (NST-EST2019- } \\
\text { 01).https://www.census.gov/data/tables/time-series/demo/popest/2010s-state- } \\
\text { total.html\#par_textimage_1574439295. }\end{array}$} \\
\hline
\end{tabular}

\section{Required and Preferred Education}

An "ALA-accredited MLIS or the international equivalent" function as a nearly universal baseline requirement across all positions in our sample. Even postings that did not require an MLIS drafted their qualifications in reference to an MLIS. For example, while a few postings only required a graduate degree, each of these also listed an MLIS degree in the preferred education section. While some positions allowed experience to be used as a substitute for meeting a required education qualification, these experience substitutions were always framed explicitly as substituting for an MLIS rather than any other advanced degree.

Only 39\% of all postings (41 of the 104) include any listed preferred education; however, more C\&UL positions, $57 \%$ (25 out of 44), included a listing for preferred education than AAHSL positions, $27 \%$ (16 out of 60), a statistically significant difference $(\mathrm{p}=0.0004)$. When listed for either type of institution, this qualification most often listed degrees that were directly relevant to a position's areas of responsibility (e.g., public health, biological sciences, etc.). Preferred education qualifications were defined in some advertisements very broadly (e.g., "health sciences;" "science or engineering related;" "physical, natural, or life sciences"), while others were substantially more specific (e.g., "basic science;" "public health;" "biomedical informatics, computational biology, data science, or similar data-intensive discipline"). 
The required experiences and skills listed in the required qualifications sections for AAHSL and C\&UL positions overlapped substantially. Through our descriptive coding process, we grouped these requirements into two categories: hard skills and soft skills. Hard skills reflected the technical skills expected of a health sciences librarian (e.g., information retrieval, information management, conducting research and producing scholarship, etc.), while soft skills reflected non-technical traits that nevertheless were necessary for success (e.g., interpersonal skills, time management, public service orientation). Table 3 includes a list of the most frequent codes associated with hard and soft skills found in postings at both AAHLs and C\&ULs, listed in alphabetical order.

Table 3. Most frequent required qualifications for positions at AAHSL and C\&UL institutions.

\begin{tabular}{|l|l|}
\hline \multicolumn{1}{|c|}{ Hard Skills } & \multicolumn{1}{|c|}{ Soft Skills } \\
\hline $\begin{array}{l}\text { Ability to or potential to meet qualifications for } \\
\text { promotion }\end{array}$ & $\begin{array}{l}\text { Ability to balance priorities and adapt in a fast } \\
\text { paced work environment }\end{array}$ \\
\hline $\begin{array}{l}\text { Commitment to and/or record of contributing } \\
\text { scholarship }\end{array}$ & $\begin{array}{l}\text { Ability to build and maintain productive } \\
\text { relationships }\end{array}$ \\
\hline $\begin{array}{l}\text { Commitment to and/or record of professional } \\
\text { growth and professional development }\end{array}$ & $\begin{array}{l}\text { Ability to work independently and as part of a } \\
\text { team }\end{array}$ \\
\hline $\begin{array}{l}\text { Evidence of and/or enthusiasm for library } \\
\text { instruction }\end{array}$ & $\begin{array}{l}\text { Demonstrated commitment to diversity, equity, } \\
\text { and inclusion and/or experience serving diverse } \\
\text { populations of users }\end{array}$ \\
\hline $\begin{array}{l}\text { Experience with and/or knowledge of relevant } \\
\text { information sources }\end{array}$ & $\begin{array}{l}\text { Demonstrated collaboration, communication, } \\
\text { and interpersonal skills }\end{array}$ \\
\hline $\begin{array}{l}\text { Expertise using citation managers } \\
\text { Knowledge of and/or ability to provide } \\
\text { reference/research support experience with } \\
\text { relevant user groups }\end{array}$ & $\begin{array}{l}\text { Evidence of problem solving, initiative, and an } \\
\text { entrepreneurial mindset }\end{array}$ \\
\hline $\begin{array}{l}\text { Knowledge of current issues in higher } \\
\text { education and academic libraries }\end{array}$ & commitment to public service \\
\hline $\begin{array}{l}\text { Knowledge of how to design and deliver user- } \\
\text { centered library services }\end{array}$ & $\begin{array}{l}\text { Understanding of scholarly communication } \\
\text { Evion and/or }\end{array}$ \\
\hline
\end{tabular}

Following our descriptive coding, we used NVivo 12 to quantify some of the most commonly reported skills we identified within the data, and other skills that did not emerge as major themes in the data despite reports of their increasing prominence elsewhere in the literature (Ma et al. 2018). Table 4 offers a definition for each of the queries run for each theme in NVivo 12, listed in alphabetical order, along with frequency of these themes within the required and preferred qualifications sections. When comparing the required qualifications for AAHLS and C\&UL PPDs, there were no statistically significant differences. There were two statistically significant differences for preferred qualifications: Academy of Health Information Professionals (AHIP) (p $=0.0042)$ and systematic reviews $(\mathrm{p}=0.0009)$. 
Table 4. NVivo 12 coded results for qualifications.

\begin{tabular}{|c|c|c|c|c|c|}
\hline \multirow{2}{*}{ Theme } & \multirow{2}{*}{ Definition } & \multicolumn{2}{|c|}{$\begin{array}{c}\text { Required } \\
\text { Qualifications }\end{array}$} & \multicolumn{2}{|c|}{$\begin{array}{c}\text { Preferred } \\
\text { Qualifications }\end{array}$} \\
\hline & & $\begin{array}{l}\text { AAHSL } \\
(\mathbf{N}=58)\end{array}$ & $\begin{array}{l}\mathrm{C} \& U L \\
(\mathrm{~N}=42)\end{array}$ & $\begin{array}{c}\text { AAHSL } \\
(\mathbf{N}=51)\end{array}$ & $\begin{array}{l}\text { C\&UL } \\
(\mathrm{N}=40)\end{array}$ \\
\hline $\begin{array}{l}\text { Academy of Health } \\
\text { Information } \\
\text { Professionals } \\
\text { (AHIP) } \\
\text { membership }\end{array}$ & $\begin{array}{l}\text { Current membership in or } \\
\text { interest in pursuing membership } \\
\text { in AHIP. }\end{array}$ & $2 \%$ & $0 \%$ & $18 \%$ & $0 \%$ \\
\hline Assessment $^{\mathrm{b}}$ & $\begin{array}{l}\text { Conducts any type of library } \\
\text { assessment activity (excluding } \\
\text { research impact assessment). }\end{array}$ & $7 \%$ & $10 \%$ & $20 \%$ & $15 \%$ \\
\hline $\begin{array}{l}\text { Collection } \\
\text { management }^{\mathrm{a}}\end{array}$ & $\begin{array}{l}\text { Builds, develops, or selects } \\
\text { library collections. }\end{array}$ & $12 \%$ & $17 \%$ & $6 \%$ & $8 \%$ \\
\hline Data science skills ${ }^{\mathrm{b}}$ & $\begin{array}{l}\text { Builds, develops, or selects } \\
\text { library collections. }\end{array}$ & $5 \%$ & $14 \%$ & $24 \%$ & $18 \%$ \\
\hline $\begin{array}{l}\text { Diversity, equity, } \\
\text { and inclusion }^{\mathrm{b}}\end{array}$ & $\begin{array}{l}\text { Works with diverse patrons or } \\
\text { shows commitment to } \\
\text { supporting diversity, equity, and } \\
\text { inclusion. }\end{array}$ & $36 \%$ & $50 \%$ & $10 \%$ & $25 \%$ \\
\hline Grant experience $^{\mathrm{b}}$ & $\begin{array}{l}\text { Applies for grants or supports } \\
\text { grant applications by other } \\
\text { researchers. }\end{array}$ & $2 \%$ & $0 \%$ & $8 \%$ & $10 \%$ \\
\hline $\begin{array}{l}\text { Instruction and } \\
\text { teaching }^{\mathrm{a}}\end{array}$ & $\begin{array}{l}\text { Designs and delivers } \\
\text { instructional content, including } \\
\text { for-credit courses, guest lectures, } \\
\text { and non-credit workshops. }\end{array}$ & $55 \%$ & $50 \%$ & $57 \%$ & $38 \%$ \\
\hline $\begin{array}{l}\text { Previous } \\
\text { professional } \\
\text { experience }^{\mathrm{a}}\end{array}$ & $\begin{array}{l}\text { Possess at least } 1 \text { year of } \\
\text { experience in a relevant setting. }\end{array}$ & $43 \%$ & $33 \%$ & $20 \%$ & $15 \%$ \\
\hline $\begin{array}{l}\text { Research impact } \\
\text { assessment }{ }^{\mathrm{b}}\end{array}$ & $\begin{array}{l}\text { Works with disciplinary faculty } \\
\text { to quantify research impact (e.g., } \\
\text { bibliometrics, researcher } \\
\text { profiles, etc.). }\end{array}$ & $7 \%$ & $12 \%$ & $12 \%$ & $8 \%$ \\
\hline Systematic reviews ${ }^{\mathrm{b}}$ & $\begin{array}{l}\text { Designs, conducts, or offers } \\
\text { consultations on systematic } \\
\text { reviews specifically, as opposed } \\
\text { to related skill sets (e.g., expert } \\
\text { searching, advanced literature } \\
\text { searching, etc.). }\end{array}$ & $5 \%$ & $0 \%$ & $24 \%$ & $0 \%$ \\
\hline a Traditional skill set & ${ }^{\mathrm{b}}$ Emerging skill set & & & & \\
\hline
\end{tabular}


There were two statistically significant differences among themes in the roles and responsibilities sections: collection management $(\mathrm{p}=0.0004)$ and systematic reviews $(\mathrm{p}=0.03)$, with collection management occurring in more C\&UL PPDs and systematic reviews occurring more frequently in AAHSL PPDs. A full break down of the frequency of themes in the roles and responsibilities section, ordered alphabetically, can be found in Table 5 .

Table 5. NVivo 12 coded results for roles and responsibilities.

\begin{tabular}{|c|c|c|c|}
\hline Theme & Definition & $\begin{array}{l}\text { AAHSL } \\
(\mathbf{N}=58)\end{array}$ & $\begin{array}{l}\text { C\&UL } \\
(\mathbf{N}=43)\end{array}$ \\
\hline Assessment ${ }^{\mathrm{b}}$ & $\begin{array}{l}\text { Conducts any type of library assessment activity } \\
\text { (excluding research impact assessment). }\end{array}$ & $40 \%$ & $56 \%$ \\
\hline $\begin{array}{l}\text { Collection } \\
\text { management }^{\text {a }}\end{array}$ & Builds, develops, or selects library collections. & $43 \%$ & $79 \%$ \\
\hline $\begin{array}{l}\text { Data science } \\
\text { skills }^{\mathrm{b}}\end{array}$ & $\begin{array}{l}\text { Supports any aspect of research data life-cycle, } \\
\text { including data visualization, data management, data } \\
\text { services, and data curation. }\end{array}$ & $31 \%$ & $40 \%$ \\
\hline $\begin{array}{l}\text { Grant } \\
\text { responsibilities }^{\mathrm{b}}\end{array}$ & $\begin{array}{l}\text { Applies for grants or supports grant applications by } \\
\text { other researchers. }\end{array}$ & $16 \%$ & $9 \%$ \\
\hline $\begin{array}{l}\text { Instruction and } \\
\text { teaching }\end{array}$ & $\begin{array}{l}\text { Designs and delivers instructional content, including } \\
\text { for-credit courses, guest lectures, and non-credit } \\
\text { workshops. }\end{array}$ & $83 \%$ & $95 \%$ \\
\hline $\begin{array}{l}\text { Research impact } \\
\text { assessment }^{\text {b }}\end{array}$ & $\begin{array}{l}\text { Works with disciplinary faculty to quantify research } \\
\text { impact, (e.g., bibliometrics, researcher profiles, etc.). }\end{array}$ & $22 \%$ & $21 \%$ \\
\hline $\begin{array}{l}\text { Systematic } \\
\text { reviews }^{\text {b }}\end{array}$ & $\begin{array}{l}\text { Designs, conducts, or offers consultations on } \\
\text { systematic reviews specifically, as opposed to related } \\
\text { skill sets (e.g., expert searching, advanced literature } \\
\text { searching, etc.). }\end{array}$ & $24 \%$ & $7 \%$ \\
\hline \multicolumn{4}{|c|}{${ }^{\mathrm{a}}$ Traditional skill set ${ }^{\mathrm{b}}$ Emerging skill set } \\
\hline
\end{tabular}

\section{Discussion}

\section{Quantitative Analysis}

This study's examination of the quantity, geographic distribution, and institutional setting of recent job advertisements for health sciences librarian positions suggests that there is a job market for health sciences librarians in many regions of the United States. Both AAHSLs and C\&ULs advertised opportunities in all 8 NNLM Regions, although no region had more C\&UL postings than AAHSL postings. While we found relevant PPDs in all 8 NNLM Regions, the clustering of these opportunities suggests that these opportunities are not equally distributed across all 8 regions, with 64 of the $104(62 \%)$ postings located in just three regions: MAR, SEA, and GMR. In our sample, SEA and GMR alone accounted for nearly half (46\%) of the sample. While SEA $(n=30)$ and GMR $(n=18)$ had the largest number of postings, these two regions also have the largest populations among the regions at 82,301,778 and 61,809,921, respectively. When taking population into account, NER $(n=6)$ had the largest postings per capita. 


\section{Required and Preferred Education}

Despite leaders within health science librarianship pointing out the need for a "diversity of degrees" within the profession, the universality of the MLIS within our data suggests that the profession continues to gravitate towards applicants with academic preparation in librarianship. Indeed, even in a recent article that attempted to highlight the various pathways that can lead towards subject librarianship, each case study highlighted included the subject pursuing and completing an MLIS degree. While institutions may welcome applicants with different advanced degrees, PPDs that continue to prioritize the MLIS degree may discourage applicants with different academic backgrounds from applying.

As others have argued, few MLIS curricula adequately prepare students for the specialized needs of health information practitioners and researchers (Detlefsen 2012), and even fewer offer substantial training in data-intensive topics (Lyon et al. 2015), suggesting that this MLIS-centric approach to hiring may limit the ability of AAHSLs and C\&ULs to meet the changing needs of their user communities. Administrators at both types of institutions may wish to consult fellowship models that have seen longstanding success in recruiting $\mathrm{PhD}$ holders from outside of libraries into the profession (Knowlton \& Imamoto 2006; Brunner 2010), with the caveat that the success of such hiring initiatives may hinge on the presence of a strategic vision for how these emerging information professionals will fit within an institution's existing services and staff (Federer et al. 2020).

The presence of a preferred educational requirement, almost always in addition to the MLIS or equivalent required qualification, was one the statistically significant differences between PPDs for AAHSL and C\&UL positions. One possible reason for the low occurrence of preferred educational requirements for AAHSL positions could be practicality. For AAHSL positions, recruiting someone with a relevant advanced degree in the health sciences (e.g., medicine, pharmacy, dentistry) could be very difficult given the amount of debt students accrue while pursuing degrees in these fields (Chisholm-Burns et al. 2019) and the comparatively low salaries libraries can offer (U.S. Bureau of Labor Statistics 2019).

\section{Required and Preferred Qualifications}

We found substantial overlap between the major themes in the required qualifications sections of AAHSL and C\&UL position descriptions, evidenced by the lack of any statistically significant differences in themes. In fact, the AAHSL and C\&UL required qualifications often looked nearly indistinguishable when viewed without identifiers (Table 6). These findings run counter to the ostensible narrative that health sciences librarians at AAHSLs would be focused on clinical support and health sciences librarians at C\&ULs would focus on research support. Rather, health sciences librarians joining $C \& U L s$ are expected to understand the relevant information sources for evidence-based practice, while many health sciences librarians at AAHSLs similarly must be aware of emerging areas of scholarly communication and research assessment. The high degree of overlap between positions at these different types of institutions suggests that hiring officials at AAHSL and C\&UL institutions may in fact be competing for candidates from the same limited applicant pool. This finding suggests that experienced librarians with expertise in supporting health and life sciences practitioners and researchers may have leverage in salary negotiations with their current or prospective employers; however, this leverage may be contingent upon the demand within a given geographic region, which our data suggest may vary. 
Table 6. Excerpts from required qualifications sections of position descriptions.

\begin{tabular}{|c|c|}
\hline C\&UL Examples & AAHSL Examples \\
\hline $\begin{array}{l}\text { "Experience in a health science library as a } \\
\text { librarian or equivalent, preferably working with } \\
\text { undergraduate and graduate students; } \\
\text { Familiarity with the health sciences or related } \\
\text { subject areas (e.g. nursing, counseling, health } \\
\text { services, etc.)."a }\end{array}$ & $\begin{array}{l}\text { "Background in working with qualitative } \\
\text { and/or quantitative research data; Experience } \\
\text { with scientific programming (such as R, } \\
\text { Python) and statistical software (such as SPSS } \\
\text { and SAS)." }\end{array}$ \\
\hline $\begin{array}{l}\text { "Academic preparation or relevant work } \\
\text { experience in animal or human health or life } \\
\text { sciences; Knowledge of evidence-based } \\
\text { practice and scholarly communication trends."c }\end{array}$ & $\begin{array}{l}\text { "Experience with research impact metrics, } \\
\text { bibliometrics and relevant related resources, } \\
\text { e.g. ORCID, VIVO-based profiles, NCBI My } \\
\text { Bibliography; Ability to work effectively with } \\
\text { faculty, staff and users."d }\end{array}$ \\
\hline $\begin{array}{l}\text { "Familiarity with research methods used in } \\
\text { public health or health-related research; } \\
\text { Understanding of the rapidly changing role of } \\
\text { the academic library and librarian in higher } \\
\text { education; Effective oral, written, and } \\
\text { interpersonal communication skills."e }\end{array}$ & $\begin{array}{l}\text { "Ability, as part of a dynamic and collaborative } \\
\text { team, to pioneer the development and } \\
\text { implementation of a vision for a comprehensive } \\
\text { research reproducibility and open science } \\
\text { program to support the university's } \\
\text { interdisciplinary research initiatives." }\end{array}$ \\
\hline \multicolumn{2}{|c|}{$\begin{array}{l}\text { a Health Sciences Librarian, Mount Saint Mary's University; }{ }^{\mathrm{b}} \text { Data Services Librarian, } \\
\text { University of Maryland - Baltimore; }{ }^{\mathrm{c}} \text { Director, William Rand Kenan, Jr. Library of Veterinary } \\
\text { Medicine, NC State University; }{ }^{\mathrm{d}} \text { Research Impact Librarian; Indiana University, Indianapolis; }{ }^{\mathrm{e}} \\
\text { Public Health Librarian, Georgia State University; }{ }^{\mathrm{f}} \text { Reproducibility Librarian, University of } \\
\text { Florida }\end{array}$} \\
\hline
\end{tabular}

Notably absent from this list of common themes at both institutions were references to the types of emerging skills that research libraries have reported investing in, such as data science skills, grant experience, research impact assessment, and open science (Burton \& Lyon 2017). While data science skills were somewhat more common within C\&UL postings, they still appeared less often than more traditional skill sets like collection management and instruction. References to grant experience and research impact assessment were low across required and preferred qualifications for positions at both types of institutions.

We found that preferred qualifications sections showed some divergence between AAHSL and C\&UL PPDs. Two themes that showed significant differences, AHIP ( $p=0.0042)$ and systematic reviews $(p=0.0009)$, were not present in any of the C\&UL PPDs. Emerging areas of librarianship, including data science skills, grant experience, and assessment, are more prevalent under preferred qualifications than required qualifications. While several of these emerging areas were higher under preferred qualifications, none of these skills occurs in more than $25 \%$ of the reviewed PPDs.

The relatively few references to AHIP membership for AAHSL positions, combined with zero references for C\&UL positions, could suggest that hiring libraries either do not value or do not understand this credential. AHIP is a "peer-reviewed, accomplishment/portfolio-based certification and career development program for health information professionals" that purports to demonstrate a professional's experiences and accomplishments (Medical Library Association 2020), so the few references to this credential within PPDs that list dozens of other desirable skills, experiences, and accomplishments is noteworthy. While additional research surveying 
hiring officials would be needed to investigate this issue further, this finding should be a point of consideration for library and information science organizations interested in launching credentialing systems like certificates or badges (American Library Association 2015), as these types of continuing education credentials may not carry much weight with prospective employers.

Qualifications related to diversity, equity, and inclusion (DEI) warrant additional consideration. Academic and medical libraries have vocally expressed their support for advancing issues related to DEI, with professional societies like the Association of College and Research Libraries (ACRL) establishing cultural competencies for academic librarians (American Library Association 2012), and the Medical Library Association creating a Diversity Task Force (Epstein 2017). However, these types of professional standards and programs have not led to substantive changes within academic libraries or librarianship. A recent systematic review found that while broader diversity initiatives aimed at creating inclusive library services are fairly common, research libraries have routinely failed to make meaningful progress in recruiting and retaining staff members from historically underrepresented minorities: "the number of visible minorities in the field has remained stagnant for decades" (Kung et al. 2020). While some institutions may hope to address these trends by including items such as diversity statements or expressing commitment to Equal Employment Opportunity/Affirmation Action within PPDs, including specific qualifications related to DEI within PPDs may be a more effective way of advancing institutional DEI by highlighting that successful incumbents will be evaluated in these areas. Some institutions have begun to integrate DEI work into all professional positions; for example, the MIT Libraries created evaluation criteria for measuring a worker's performance in these areas (Baildon et al. 2017).

Given the broad exposure this proposal from MIT Libraries gained in the spring of 2017 (Amundsen 2017; Baildon 2018), the 2018-2019 academic year presented an appropriate time point for examining whether this had impacted the framing of positions within other institutions. In our sample, we found DEI related experiences in the required and preferred qualifications sections reflected in a variety of ways, such as "supporting diverse user groups" or "working in an environment that encourages and supports individuals regardless of background." In C\&ULs, a DEI requirement was one of the most frequently referenced skills. This represents a remarkable growth in a relatively short period of time; in an analyses of roles for health sciences librarians from 1990-2012, the word diversity does not appear even once (Cooper \& Crum 2013).

Relatedly, across required and preferred qualifications at both AAHSLs and C\&ULs, some skills required that applicants show "demonstrated ability to or knowledge of," while others required "an enthusiasm or willingness to learn about." The construction of these phrases may reflect several different things. Primarily, this difference may provide insights into what hiring officials view as traits or skills that are absolutely required versus areas a successful candidate might be able to develop over time. For example, soft skill qualifications like "work successfully with others," "develop relationships with diverse user communities," and "ability to communicate effectively" were often paired with the phrase "demonstrated ability to." This may suggest that hiring officials may view these "soft skills" as either more essential or harder to develop within a staff member. Meanwhile, specialized hard skills like data science skills or research impact assessment often were listed under the "enthusiasm for" category. Hiring officials may make this decision based on their perceptions of whether a trait can be learned, or how hard it will be to find a potential applicant with a given skill. It is also possible that hiring officials are wary of limiting their pool of applicants by requiring numerous hard skills; however, the inclusion of phrases like "enthusiasm for" or "passion for" may create additional equity issues to consider. While hiring officials can use references to verify whether applicants have experience completing specific types of tasks, ascertaining their level of passion or enthusiasm for the task 
creates potential opportunities for implicit bias to interfere with the recruitment process. These implicit biases are likely to favor applicants who hiring officials view as "naturals" who "fit" into their organization (Carroll \& Klipfel 2019); these are labels that likely will reflect the systemic biases within academic libraries and higher education more broadly (Bourg 2014; Hathcock 2015). Consequently, library administrators committed to advancing institutional equity should reconsider the use of subjective criteria such as enthusiasm or passion.

\section{Roles and Responsibilities}

Looking at the roles and responsibilities also shows a vision for what potential hires will do in the position, not what they have done previously. Yet in these sections, we again find that traditional responsibilities (e.g., reference, teaching, collection management) are more prevalent than emerging areas (data science skills, systematic reviews, grant experience, assessment); however, this section does show the largest number of mentions of emerging skills. For instance, assessment shows up at higher frequency (AAHSL 40\% and C\&UL 56\%) than the combined occurrence in the required and preferred qualification sections (AAHSL 27\% and C\&UL 25\%).

The same is true for systematic reviews in C\&ULs PPDs, where despite no mentions in either qualification section, they occurred in $7 \%$ of the roles and responsibilities. The overall low occurrence may indicate a missed opportunity for C\&ULs, since systematic reviews have begun to be published in fields like engineering (Ferreira dos Santos et al. 2016), biology (Driscoll et al. 2014), and psychology (van de Schoot et al. 2017). This suggests that researchers at many of these institutions are conducting systematic reviews and could benefit from working with a librarian well-versed in systematic reviews. By recruiting librarians with experience in systematic reviews, C\&ULs would be better positioned to both support disciplinary researchers interested in applying the method and promote skill development in this area among their existing library staff. It is worth noting that systematic reviews were not frequently discussed for positions at AAHSLs either, despite the prevalence of these services across AAHSLs, systematic reviews were included in just under $25 \%$ of AAHSL PPD roles and responsibilities section. This finding is incongruent with the stated priorities of most health information professionals and hard to reconcile. One possible explanation is that the human resources professionals and library administrators designing PPDs are assuming that candidates will understand intuitively that responsibilities like "providing liaison services" may include assisting with systematic reviews in their assigned areas. Given the continued popularity of continuing education opportunities aimed specifically at helping experienced librarians develop the unique skills needed to assist with systematic reviews (University of Michigan Libraries 2020), this assumption may be ill-founded.

Collection management is another example where there is an increased occurrence in the roles and responsibilities section within C\&ULs PPDs despite a relative dearth of references in either qualification section. The lack of required or preferred experience combined with higher occurrence in the roles and responsibilities section, suggests that hiring libraries are confident in the ability of successful hires to be able to perform the level of collections responsibilities with or without previous experience. Collection management also represents one of the statistically significant differences between roles and responsibilities between AAHLS and C\&UL PPDs. One potential reason why C\&ULs mention collections more often could be a reflection of the organization structure of the two types of institutions. It is possible that given the often broader scope of disciplines found in C\&ULs, those libraries need their librarians to provide more support in collection management, whereas AAHSLs may be able to have a dedicated collection management person or team who are able to handle collection management, perhaps with input from other members of the organization. With collection management having the second largest thematic occurrence in both groups, traditional skills are still very much expected of new hires. 


\section{Limitations}

There are several noteworthy limitations to this study. Our methods created the opportunity for discovery bias for both AAHSL and C\&UL positions based on the search strategy used to identify potentially relevant PPDs. Because most position descriptions within AAHSL would likely include one of the terms or phrases in our inclusion criteria, our strategy was more likely to identify PPDs within AAHSLs than in C\&ULs that fell outside of subject specialist roles. This may have led to the inclusion of more functional specialists (e.g., scholarly communication librarian, research data librarian, etc.) from AAHSLs than from C\&ULs. It is also possible that specific liaison positions could have been missed because we did not include those specific terms in our search (e.g., dentistry, physical therapy, etc.); however, our strategy would have captured those positions if they included one of the keywords we did include (as demonstrated by our search finding a dental liaison position).

While our study included a geographic analysis, this analysis was limited to the United States. Future authors may wish to collaborate with Canadian researchers to produce a knowledge synthesis study that will systematically compare and contrast the findings of this study with the results of similar studies focused on Canadian institutions (Thorne 2019). The use of national job boards rather than regional job boards, which often require paying a posting fee, may have underrepresented specific regions or institutions that cannot afford to pay for posting on larger sites. We attempted to mitigate this by hand searching a select group of related listservs, but it is possible postings were missed. Within the included PPDs, a recurring limitation was the lack of standardization in formatting within position descriptions. The lack of standardized language for common tasks also complicated the analysis process. Finally, our six-month sample presents a relatively small, static depiction of a situation that is constantly evolving. If a different time period was studied, other regions may have had more opportunities. Future researchers interested in tracking the geographic distributions of health sciences librarian positions may wish to consider using a longer timeframe to identify whether these trends remain consistent over a larger sample.

\section{Conclusion}

Library administrators seeking to provide value-added services to their institutions are wellserved by "shift[ing] from thinking about the user in the life of the library to thinking about the library in the life of the user;" such a shift should be reflected by changes to position descriptions (Dempsey 2016). Our findings both challenge and corroborate the conclusions drawn in related studies of whether such changes are being reflected in position descriptions, while adding a geographic analysis that has yet to be included in previous work. In their systematic review, Cooper and Crum (2013) outlined several new technical responsibilities for health sciences librarians drawn from the published literature, including systematic reviews, emerging technologies, grant experience, and data management, among others. Based on their findings, Cooper and Crum (2013) suggested that these roles portended "major changes in how health sciences librarians serve their institutions." In contrast, our sample aligns more closely with the conclusions of Reed and Butkovich (2017) who noted that while data-intensive roles across academic STEM and medical librarian positions became more prevalent between 2005 and 2014, these positions frequently retained responsibilities in traditional areas like reference and collections management. Our findings also align with those of Bychowski et al. (2010) who found that PPDs in a ten year sample "revealed surprisingly few changes in the requirements for science librarian positions...suggest[ing] that what employers are looking for has not changed in spite of the changes in the profession." 
Front-line public services librarian positions represent one of the largest human resources investments academic libraries make; as a result, the roles and responsibilities of these positions provide meaningful insights into the strategic priorities of an academic library (Pinfield 2001). When envisioning new positions within their libraries, library administrators should aim to design user-centered positions that reflect the needs of their local communities rather than chasing emerging trends reported in the literature (Federer et al. 2020). If library administrators and hiring officials at AAHSLs and C\&ULs have determined that new services (e.g., systematic reviews, grant experience, data science skills, etc.) could fill gaps in their institution's current service offerings, and want to follow through on their stated intentions of hiring librarians with the necessary knowledge, skills, and abilities to offer these services, some of the standard elements of public services position descriptions may need to be updated to reflect these changes in priorities. Potential changes could include: de-emphasizing the importance of the MLIS; removing traditional librarian skill sets like reference services from required and preferred experience sections; replacing technical library jargon with language that is more inclusive for applicants from different backgrounds; and adding in specific responsibilities for advancing institutional DEI. While traditional requirements like an MLIS degree or collection management historically have been necessities for working in an academic library, such requirements may now reflect a library-centric rather than user-centric frame of thinking.

\section{Data Availability Statement}

Data associated with this article are available in the Open Science Framework (Carroll \& Reed $\underline{2019 c})$.

\section{References}

American Library Association. 2012 Diversity standards: cultural competency for academic libraries [Internet]. Chicago (IL): Association of College \& Research Libraries. [cited 2020 Jan 21]. Available from: http://www.ala.org/acrl/standards/diversity.

American Library Association. 2015. Badging [Internet]. Chicago (IL): American Library Association. [cited 2019 Oct 15]. Available from: http://www.ilovelibraries.org/librariestransform/badging.

American Library Association. n.d. ALA JobLIST: jobs in library \& information science \& technology [Internet]. Chicago (IL): American Library Association. [cited 2019 May 17]. Available from: https://joblist.ala.org?site_id=21926.

Amundsen, J. 2017. Equity, diversity, and inclusion: dispatches from ACRL [Internet]. Chicago (IL): Association of College \& Research Libraries. [cited 2020 Jan 21]. Available from: https://americanlibrariesmagazine.org/blogs/the-scoop/equity-diversity-inclusion-dispatches-acrl.

Association of Academic Health Sciences Libraries. 2019. About AAHSL [Internet]. Seattle (WA): Association of Academic Health Sciences Libraries. [cited 2019 Oct 14]. Available from: https://www.aahsl.org/about-us.

Association of College \& Research Libraries Health Sciences Interest Group. 2019. ACRLHSIG Archives [Internet]. Chicago (IL): Association of College \& Research Libraries. [cited 2019 May 17]. Available from: https://lists.purdue.edu/pipermail/acrl-hsig. 
Association of College \& Research Libraries Science \& Technology Section. 2019. STS-L: ACRL Science \& Technology Section discussion list [Internet]. Chicago (IL): Association of College \& Research Libraries. [cited 2019 May 17]. Available from:

http://lists.ala.org/sympa/arc/sts-1.

Baildon, M. 2018. Extending the social justice mindset: implications for scholarly communication. College \& Research Libraries News 79(4):176-179. DOI: $\underline{10.5860 / \mathrm{crln} .79 .4 .176 .}$

Baildon, M., Hamlin, D., Jankowski, C., Kauffman, R., Lanigan, J., Miller, M., Venlet, J. \& Willer, A.M. 2017. Creating a social justice mindset: diversity, inclusion, and social justice in the Collections Directorate of the MIT Libraries [Internet]. Cambridge (MA): MIT Libraries. [cited 2020 Jan 21]. Available from: http://hdl.handle.net/1721.1/108771.

Beile, P.M. \& Adams, M.M. 2000. Other duties as assigned: emerging trends in the academic library job market. College \& Research Libraries 61(4):336-347. DOI: http://dx.doi.org/10.5860/crl.61.4.336.

Birks, M. \& Mills, J. 2011. Grounded theory: a practical guide. London: Sage.

Bourg, C. 2014. The unbearable whiteness of librarianship. Feral librarian [Internet]. [cited 2018 Sep 5]. Available from: https://chrisbourg.wordpress.com/2014/03/03/the-unbearable-whitenessof-librarianship.

Brunner, M.L. 2010. Ph.D. holders in the academic library: the CLIR postdoctoral fellowship program [Internet]. In: Walter S., Coleman V., Williams K., editors. The expert library: staffing, sustaining, and advancing the academic library in the 21st century. Chicago (IL): Association of College \& Research Libraries. [cited 2019 Jul 1]. Available from:

https://escholarship.org/uc/item/05j228r4.

Burton, M. \& Lyon, L. 2017. Data science in libraries. Bulletin of the Association for Information Science and Technology. 43(4):33-35. DOI: 10.1002/bul2.2017.1720430409.

Bychowski, B.K.H., Caffrey, C.M., Costa, M.C., Moore, A.D., Sudhakaran, J. \& Zhang, Y. 2010. Old words, new meanings: a study of trends in science librarian job ads. Issues in Science and Technology Librarianship. 63. DOI: 10.5062/F47D2S2K.

Carroll, A.J., Eskridge, H.N. \& Chang, B.P. 2020. Lab-integrated librarians: a model for research engagement. College \& Research Libraries. 81(1):8-26. DOI: 10.5860/crl.81.1.8.

Carroll, A.J. \& Klipfel, K.M. 2019. Talent, schmalent: an instructional design/action research framework for the professionalization of teaching in academic libraries. The Journal of Academic Librarianship. 45(2):110-118. DOI: 10.1016/j.acalib.2019.01.009.

Carroll, A.J. \& Reed, J.B. 2019a. 2018 AAHSL member directory. Open Science Framework. Charlottesville (VA): Center for Open Science. DOI: 10.17605/OSF.IO/WCBZR.

Carroll, A.J. \& Reed, J.B. 2019b. Collected position descriptions data sheet. Open Science Framework. Charlottesville (VA): Center for Open Science. DOI: 10.17605/OSF.IO/XQC7T. 
Carroll, A.J. \& Reed, J.B. 2019c. Investigating roles for health sciences librarians at college and university libraries. Open Science Framework. Charlottesville (VA): Center for Open Science. DOI: $10.17605 / O S F . I O / Q R W 7 K$.

Chisholm-Burns, M.A., Spivey, C.A., Stallworth, S. \& Zivin, J.G. 2019. Educational debt crisis: analysis of debt and income among pharmacists, physicians, dentists, optometrists, and veterinarians. American Journal of Pharmaceutical Education. 83(9):7460 DOI: 10.5688/ajpe7460.

Cimellaro, G.P., Reinhorn, A.M. \& Bruneau, M. 2010. Framework for analytical quantification of disaster resilience. Engineering Structures. 32(11):3639-3649. DOI: 10.1016/j.engstruct.2010.08.008.

Cooper, I.D. \& Crum, J.A. 2013. New activities and changing roles of health sciences librarians: a systematic review, 1990-2012. Journal of the Medical Library Association. 101(4):268-277. DOI: 10.3163/1536-5050.101.4.00.

Crum, J.A. \& Cooper, I.D. 2013. Emerging roles for biomedical librarians: a survey of current practice, challenges, and changes. Journal of the Medical Library Association. 101(4):278-286. DOI: $\underline{10.3163 / 1536-5050.101 .4 .009 .}$.

Dempsey, L. 2016. Library collections in the life of the user: two directions. LIBER Quarterly. 26(4):338. DOI: 10.18352/lq.10170.

Detlefsen, E.G. 2012. Teaching about teaching and instruction on instruction: a challenge for health sciences library education. Journal of the Medical Library Association. 100(4):244-250. DOI: $10.3163 / 1536-5050.100 .4 .005$.

Douglas-Williams, T., Linares, B. \& Lindsay, J.M. 2019. Diversity in degrees in libraries. In: Proceedings of the 2019 Medical Library Association Annual Meeting and Exhibition. Chicago (IL): Medical Library Association.

Driscoll, D.A., Banks, S.C., Barton, P.S., Ikin, K., Lentini, P., Lindenmayer, D.B., Smith, A.L., Berry, L.E., Burns, E.L., Edworthy, A., et al. 2014. The trajectory of dispersal research in conservation biology: systematic review. PLOS ONE 9(4). DOI: 10.1371/journal.pone.0095053.

Epstein, B. 2017. Newly appointed diversity task force announced [Internet]. Full Speed Ahead. Chicago (IL): Medical Library Association. [cited 2020 Jan 22]. Available from: https://www.mlanet.org/blog/newly-appointed-diversity-task-force.

Federer, L., Clarke, S.C., Zaringhalam, M. \& Huerta, M. 2020. Developing the librarian workforce for data science and open science. Bethesda (MD): National Library of Medicine. DOI: $10.31219 /$ osf.io/.

Ferreira dos Santos, L., Christ, O., Mate, K., Schmidt, H., Kr\&uumlger, J. \& Dohle, C. 2016. Movement visualisation in virtual reality rehabilitation of the lower limb: a systematic review. BioMedical Engineering OnLine. 15(3):144. DOI: 10.1186/s 12938-016-0289-4.

Glaser, B. \& Strauss, A. 2000. The discovery of grounded theory: strategies for qualitative research. New Brunswick (NJ): Routledge. 
Grimes, M.F. \& Grimes, P.W. 2008. The academic librarian labor market and the role of the master of library science degree: 1975 through 2005. The Journal of Academic Librarianship. 34(4):332-339. DOI: 10.1016/j.acalib.2008.05.023.

Hahn, K. 2009. Introduction: positioning liaison librarians for the 21st century. Research Library Issues. no. 265(1-2). DOI: 10.29242/rli.265.1.

Hathcock, A. 2015.White librarianship in blackface: diversity initiatives in LIS [Internet]. In the Library with the Lead Pipe. [cited 2018 Sep 5]. Available from: http://www.inthelibrarywiththeleadpipe.org/2015/lis-diversity/.

Hernon, P. \& Schwartz, C. 2015.Descriptions in job ads sometimes equal "Huh?", or "Do you know what you are asking for?" Library \& Information Science Research. 37(3):173-174. DOI: 10.1016/j.lisr.2015.08.001.

Holden, R.J., Carayon, P., Gurses, A.P., Hoonakker, P., Hundt, A.S., Ozok, A.A. \& RiveraRodriguez, A.J. 2013. SEIPS 2.0: a human factors framework for studying and improving the work of healthcare professionals and patients. Ergonomics. 56(11):1669-1686. DOI: 10.1080/00140139.2013.838643.

Hoodless, C. \& Pinfield, S. 2018. Subject vs. functional: should subject librarians be replaced by functional specialists in academic libraries? Journal of Librarianship and Information Science. 50(4):345-360. DOI: 10.1177/0961000616653647.

Hurd, J.M. 1992. Interdisciplinary research in the sciences: implications for library organization. College \& Research Libraries. 53(4):283-297. DOI: 10.5860/crl_53_04_283.

Jaguszewski, J.M. \& Williams, K. 2013. New roles for new times: transforming liaison roles in research libraries. Washington (DC): Association of Research Libraries.

Knapp, J.A. 2012. Plugging the "whole": librarians as interdisciplinary facilitators. Library Review. DOI: 10.1108/00242531211259328.

Knowlton, S.P. \& Imamoto, B. 2006. Recruiting non-MLIS graduate students to academic librarianship. College \& Research Libraries. 67(6):561-570. DOI: 10.5860/crl.67.6.561.

Korosteleva, O. 2018. Fisher exact test. In: Frey, B., editor. The SAGE encyclopedia of educational research, measurement, and evaluation. Vol. 1. Thousand Oaks (CA): SAGE Publications. p. 679-682. DOI: 10.4135/9781506326139.n266.

Kung, J., Fraser, K.L. \& Winn, D. 2020. Diversity initiatives to recruit and retain academic librarians: a systematic review. College \& Research Libraries. 81(1):96-108. DOI: $\underline{10.5860 / \mathrm{crl} .81 .1 .9 .}$.

Leckie, G.J., Pettigrew, K.E. \& Sylvain, C. 1996. Modeling the information seeking of professionals: a general model derived from research on engineers, health care professionals, and lawyers. The Library Quarterly: Information, Community, Policy. 66(2):161-193.

Lyon, L., Mattern, E., Acker, A. \& Langmead, A. 2015. Applying Translational Principles to Data Science Curriculum Development. In: iPres 2015 Proceedings; 2015 Nov 2-6 Chapel Hill (NC).Available from: http://d-scholarship.pitt.edu/27159/. 
Ma, J., Stahl, L. \& Knotts, E. 2018. Emerging roles of health information professionals for library and information science curriculum development: a scoping review. Journal of the Medical Library Association. 106(4):432-444. DOI: 10.5195/jmla.2018.354.

Mathews, J.M. \& Pardue, H. 2009. The presence of IT skill sets in librarian position announcements. College \& Research Libraries. 70(3):250-257. DOI: $\underline{10.5860 / \mathrm{crl} .70 .3 .250}$.

Medical Library Association. 2019a. MLA find a job [Internet]. Chicago (IL): Medical Library Association. [cited 2019 May 17]. Available from: https://www.mlanet.org/p/cm/ld/fid=46.

Medical Library Association. 2019b. MEDLIB-L [Internet]. Chicago (IL): Medical Library Association. [cited 2019 May 17]. Available from: https://list.uvm.edu/cgi-bin/wa?A0=medlib-l.

Medical Library Association. 2020. AHIP credentialing [Internet]. Chicago (IL): Medical Library Association. [cited 2020 Jan 27]. Available from: https://www.mlanet.org/academy.

National Network of Libraries of Medicine. 2019. Regional medical libraries [Internet]. Bethesda (MD): National Network of Libraries of Medicine. [cited 2019 May 17]. Available from: https://nnlm.gov/regions.

National Science Foundation. n.d. Introduction to interdisciplinary research. Alexandria (VA): National Science Foundation. [cited 2019 Oct 15]. Available from: https://www.nsf.gov/od/oia/additional_resources/interdisciplinary_research/index.jsp.

Pinfield, S. 2001. The changing role of subject librarians in academic libraries. Journal of Librarianship and Information Science. 33(1):32-38. DOI: 10.1177/096100060103300104.

Pothier, W.G., Howard, H. \& Campbell, P. 2019. Pathways to becoming an academic subject specialist: insights from three librarians. Partnership. 14(1). DOI:

10.21083/partnership.v14i1.5172.

Reed, J.B. \& Carroll, A.J. 2019. NVivo queries. Open Science Framework. Charlottesville (VA): Center for Open Science. DOI: 10.17605/OSF.IO/HSVJK.

Reed, R.B. \& Butkovich, N.J. 2017. Comparison of data and informatics responsibilities and job titles between academic stem and medical librarians. Issues in Science and Technology Librarianship. 87. DOI: 10.5062/F4V40SFK.

Reser, D.W. \& Schuneman, A.P. 1992. The academic library job market: a content analysis comparing public and technical services. College \& Research Libraries. 53(1):49-59. DOI: $\underline{10.5860 / \mathrm{crl} 53}$ [01_49.

Rockenbach, B. 2018. What are we trying to build? Research Library Issues. (294):3-7. DOI: 10.29242/rli.294.1.

Rodwell, J. \& Fairbairn, L. 2008. Dangerous liaisons? defining the faculty liaison librarian service model, its effectiveness and sustainability. Library Management. 29(1/2):116-124. DOI: $\underline{10.1108 / 01435120810844694 .}$.

Saldana, J. 2015. The coding manual for qualitative researchers. 3rd edition. London: SAGE Publications. 
Thorne, L. 2019. What employers really, really want: investigating desired qualifications in health sciences library job postings. In: CHLA 2019 Conference Contributed Papers / ABSC Congr\&eacutes 2019 Communications Libres. Ottawa (ON): Children's Literature Association.

Trei, K. 2015. Science, technology, engineering and math (STEM) academic librarian positions during 2013: what Carnegie Classifications reveal about desired STEM skills. Issues in Science and Technology Librarianship. 80. DOI: 10.5062/F4XG9P57.

Triumph, T.F. \& Beile, P.M. 2015. The trending academic library job market: an analysis of library position announcements from 2011 with comparisons to 1996 and 1988. College \& Research Libraries. 76(6):716-739. DOI: 10.5860/crl.76.6.716.

University of Michigan Libraries. 2020. Systematic reviews: opportunities for librarians [Internet]. Ann Arbor (MI): University of Michigan Libraries. [cited 2020 Feb 12]. Available from: https://www.lib.umich.edu/systematic-reviews-workshop.

van de Schoot, R., Winter, S.D., Ryan, O., Zondervan-Zwijnenburg, M. \& Depaoli, S. 2017. A systematic review of Bayesian articles in psychology: the last 25 years. Psychological Methods. 22(2):217-239. DOI: $10.1037 / \operatorname{met} 0000100$.

U.S. Bureau of Labor Statistics. 2019. Librarians [Internet]. Occupational Outlook Handbook. Washington (DC): U.S. Bureau of Labor Statistics. [cited 2020 Feb 12]. Available from: https://www.bls.gov/ooh/education-training-and-library/librarians.htm\#tab-1. 